\title{
Community-Based Mangrove Rehabilitation: The Case of Calatagan Mangrove Park- Marine Protected Area, Batangas, Philippines
}

\author{
Mark Joseph J. Buncag, MSc ${ }^{1}$, William M. Esguerra ${ }^{2}$, and Asnawi D. Linga ${ }^{3}$ \\ ${ }^{1}$ Faculty, Palawan State University, Palawan, Philippines, Philippines \\ ${ }^{2} M S$ in Forestry Student, University of the Philippines Los Baños \\ ${ }^{3}$ Faculty, Mindanao State University Marawi Campus, Philippines
}

\begin{abstract}
Mangroves support several forms of life, including terrestrial animals, marine animals and humans by providing direct benefits like a source of food and indirect benefits like a buffer against disasters and coastal protection. Community-based mangrove rehabilitation strengthening the benefits that can be availed by the community from mangrove forests for their well-being. This study mainly aimed to evaluate the Communitybased Mangrove Rehabilitation in Quilitisan, Calatagan Mangrove Park- Marine Protected Area, Batangas. Specifically, described the progress of mangrove rehabilitation, assessed the major issues and concerns in Mangrove Rehabilitation, identified the best practices and strategies in Mangrove Rehabilitation, and identified the key considerations in mangrove rehabilitation in terms of policy and institution, scientific and ecological preferences, participatory approaches. This study utilized qualitative criteria which answered using Key Informant Interviews (KII). Results stated that through the cooperation of government agencies, nongovernment organizations and the local community through people's organization (PO), PALITAKAN (Pro Mangrove Alliance Implementing Team as Arm Quilitisan Advocate of Nature), the mangroves planted to rehabilitate the area and survived after seven years with $80 \%$ survival rate. The community is currently getting natural resources for both household and commercial uses and uses the area for ecotourism activities. However, the PO faces issues and concerns with regard to management. In addition, there are some best practices in planting, monitoring, management and livelihood activities and some key considerations in rehabilitation in terms of policy and institution, scientific and ecological preferences, participatory approaches.
\end{abstract}

Keywords: mangrove rehabilitation, issues and concerns, best practices and key considerations

\section{INTRODUCTION}

Mangrove forests are very useful and productive tropical forests that provide goods and services to living organisms (UNU-INWEH, 2016). It supports several forms of life, including terrestrial animals, marine animals and humans (Carter et al. 2015). It offers great numbers of goods like timber and fuelwood (FAO 2007). Apart from their ecological importance, mangrove provides aesthetic, historical and cultural values (Grasso, 2000). It also provides indirect benefits such as their ability to absorb wave energy and serve as buffers against storms (Daupan, 2016), their ability to filter the water from sediments before flowing unto the sea (Hema and Indira Devi, 2013), a natural habitat for birds and marine life forms, including its function as nurseries and spawning grounds for marine life forms such as shrimp and milkfish and a source of food for marine fauna through detritus food chain (Daupan, 2016).

For the past decades, there has been a huge decrease in areas occupied by mangrove trees in the Philippines. At present, the mangrove forest cover in the country is estimated at about 310,593 hectares (DENR, 2015), having dwindled from 450,000 ha in 1918 (Naz, 2012-2013). This significant loss of mangrove forests 
can be attributed to anthropogenic activities, especially to the conversion of mangrove forests to fishponds. From 1973 to 2002, a total of 62,834.34 hectares of mangrove forest areas across the country were issued with Fishpond Lease Agreements (FLAs) by the Bureau of Fisheries and Aquatic Resources (BFAR), consequently converting these forests into fishponds (Naz, 2012-2013).

In response to mangrove deterioration, mangrove rehabilitation is being conducted. However, the sustainability of mangrove forest rehabilitation is not only depending on the continuous planting but through the involvement of the community in the management. The local community can directly affect the mangrove forest for the reason that they are living near the area (Daupan, 2016). In addition, the cooperation of the local and national government to the local community is more efficient in securing the mangrove conservation due to the complexity of the mangrove ecosystem (Carter et al. 2015). Like in the case of mangrove rehabilitation in Bgy. Quilitisan, Catalagan, Batangas, the local people through a peoples' organization named, PALITAKAN (Pro Mangrove Alliance Implementing Team as Arm Quilitisan Advocate of Nature) initiated the rehabilitation through the support of different agencies like Conservation International (CI). Livelihood opportunities, food production and resiliency against disasters are their primary objective in the rehabilitation which started in the year 2010. Currently, the local people particularly the PO are gaining benefits from the mangrove forest in terms of ecotourism activities present in the area and fish production for both household and commercial use and the mangrove rehabilitation project is being managed by the said PO.

The main objective was to evaluate the Community-based Mangrove Rehabilitation in Quilitisan, Calatagan Mangrove Park- Marine Protected Area, Batangas. Specifically, this study aimed to describe the progress of mangrove rehabilitation; to assess the major issues and concerns in Mangrove Rehabilitation, to identify the best practices and strategies in Mangrove Rehabilitation

And to identify the key considerations in Mangrove Rehabilitation in terms of: Policy and Institution, Scientific and Ecological Preferences, Participatory Approaches.

\section{CONCEPTUAL FRAMEWORK}

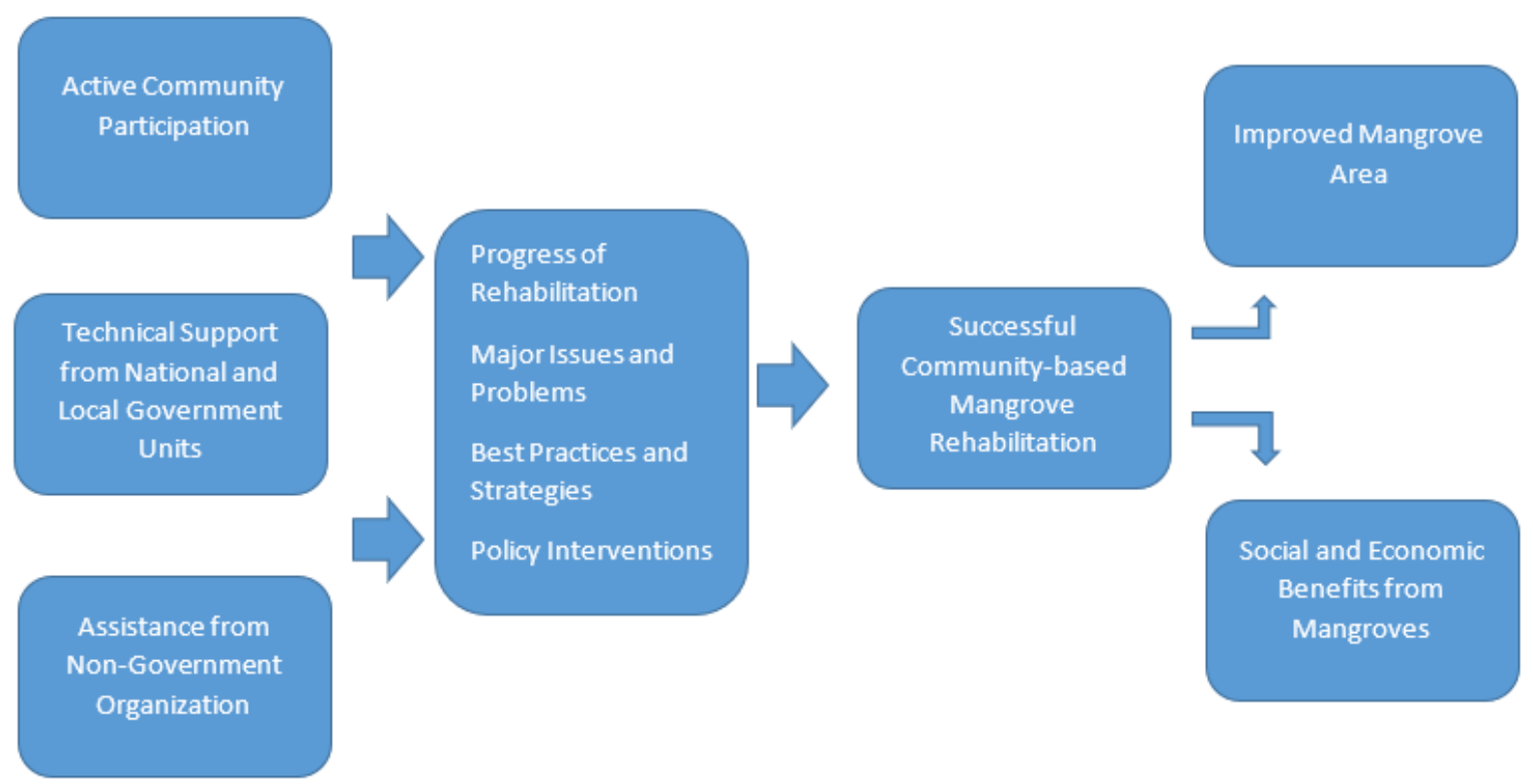

Figure 1. Conceptual Framework 
Figure 1 shows the relationship among variables present in the evaluation of mangrove rehabilitation in Quilitisan, Calatagan Batangas. The Mangrove rehabilitation that took place in Calatagan was a result of the collaboration of support (technical and financial support from the local, national government agencies and nongovernment organizations) and active community participation. The significant factors in evaluating the community-based mangrove rehabilitation are the progress of mangrove rehabilitation, issues and concerns, best practices and strategies in rehabilitation and policy interventions. A successful mangrove rehabilitation will result in an improved mangrove ecosystem but ultimately will provide social (protection from calamities) and economic (alternative livelihood for tourism and fishing) benefits to the community.

\section{RESEARCH METHOD}

This study was conducted in Barangay Quilitisan, Calatagan, one of the municipalities of the province of Batangas where Calatagan Mangrove Forest Conservation Park is located (120³6'58.2" longitude and $13^{\circ} 53^{\prime} 0.9^{\prime \prime}$ latitude). It is a community-based marine protected area that is being managed by the PO named PALITAKAN (Pro-Mangrove Alliance Implementing Team as Arm Quilitisan Advocate of Nature) in cooperation with Barangay Government of Quilitisan, Calatagan.

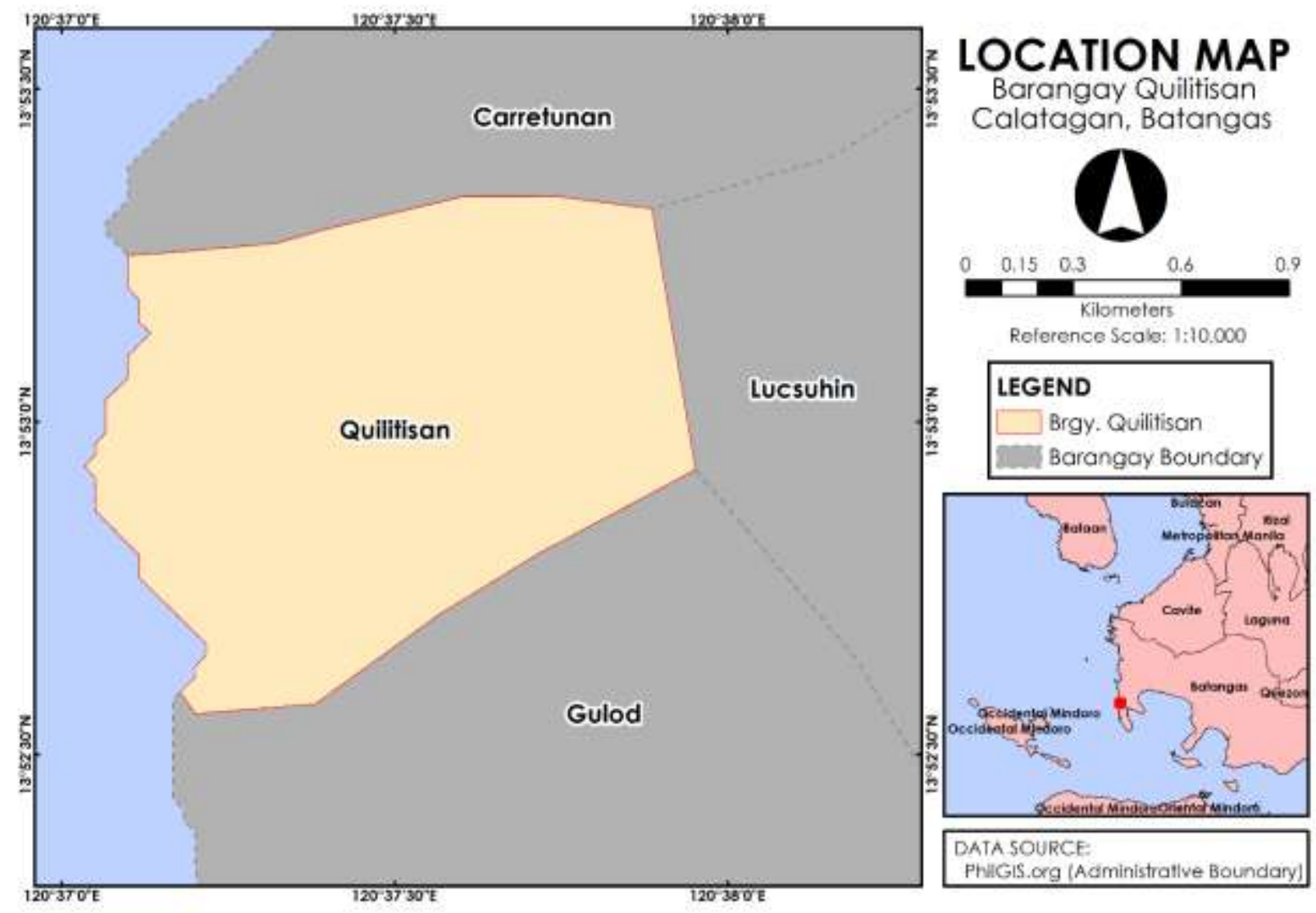

Figure 2. Location Map of Barangay Quilitisan, Calatagan, Batangas

This study utilized qualitative criteria to evaluate the mangrove rehabilitation in Quilitisan, Calatagan which includes: key project objectives, location and site area, duration of rehabilitation, Peoples' Organization (PO) participation and management, biophysical condition, funding institutions, institutions involved, methods and techniques, survival rate, activities, issues and concerns, success factors, impacts and benefits, resiliency and key policies. This was evaluated through a qualitative approach. In gathering data, the researchers used Key 
Informant Interviews (KII) through guide questions to the officers and members of PO and Secondary Data Analysis.

This study also adopted narrative research $=$ co-construction (constructivist ontological stance). Creswell (2014), the researcher asks one or more individuals to provide "stories about their lives...[which] is retold or restoried by the researcher into a narrative chronology [thereby combining] views from the participant's life with those of the researcher's life in a collaborative narrative." Merriam (2009), "the researcher is the primary instrument for data collection and analysis.

\section{RESULTS}

\subsection{Progress of Mangrove Rehabilitation}

It was in the year 2010 when the Conservation International (CI) visited the Bgy. Quilitisan, Calatagan, Batangas. Armed with motivation and scientific knowledge, the CI has shared this knowledge and motivation to the people of Bgy. Quilitisan to save the remaining mangrove forest. The CI initiated the ecotourism development in the area by construction of a boardwalk and watch tower amounting to Php 300,000.00. In addition, CI facilitated training on leadership and values formation. From there, a group of 20 members from the Bgy.formed their Peoples Organization namely PALITAKAN (Pro Mangrove Alliance Implementing Team as Arm Quilitisan Advocate of Nature). In 2010, The PO started to rehabilitate the mangrove area with the support of DENR and MENRO and funds came from the income in ecotourism (Php 1.00 per propagule with 10,000 propagules planted). For five years, CI taught the members of the PO about the science of rehabilitating their mangrove forests from seed collection, to nursery growing of propagules, field out planting and maintenance and protection. With a survival rate of approximately $80 \%$ for propagules and $50 \%$ from seedlings, the rehabilitation of the mangrove forests was successful. The effects of the success of the mangrove rehabilitation are now being endowed by the PO and the Community as well. A variety of fishes for human consumption have become abundant. Crabs, shrimps and other crustaceans are also available as a source of additional income for the PO members. In 2013, the PO became registered in the Security and Exchange Commission (SEC).

Since the recognition of the PO in 2013, donations from different sectors have poured. The Ayala Zobel Foundation donated 60,000 pesos. Senator Loren Legarda has donated Php 1,500,000.00 for the renovation of a boardwalk (concrete) and 2 motorized banca for the utilization of the PO for ecotourism and mobilization purposes. As part of their alternative livelihood, last February 2018, the Bureau of Fisheries and Aquatic Resources (BFAR), provided a Halaan production with the support of the Municipal Agriculture Office (MAO).

A total of 7.5 hectares of sustainably managed mangrove forests have been restored by the PO. These are composed of 2 islets, (4.5 and 3 hectares respectively). The first islet (4.5 hectares) is now an eco-tourism spot of Brgy. Quilitisan in Calatagan, Batangas. Co-managed with the Local Government of Brgy. Quilitisan and Municipality of Calatagan, ecotourism offers activities such as, canopy walking, swimming, picnic, and even snorkeling. Amenities such as boat riding, cottages and even view deck are enjoyed by patriots. Proceeds for these activities and amenities are distributed to the PO, Brgy. and Municipality.The other three-hectare islet is now adopted by National University as their experimental area for mangroves. The protection and preservation of this islet are shared between the PO and NU.

\subsection{Major Issues and Concerns in Mangrove Rehabilitation}

The major issues and concerns in their mangrove rehabilitation are the free-riders from the other or adjacent places, insufficient manpower for monitoring and lack of funds for maintenance and monitoring the 7.5 hectares everyday and stealing of some equipment in the rehabilitation area. The PO named PALITAKAN (ProMangrove Alliance Implementing Team as Arm Quilitisan Advocate of Nature) highly considered the freeriders as a major threat to their rehabilitation. The free-riders are cutting mangroves for both commercial and household uses. Their usual target for poaching is the mangrove trees situated on the inner part of the mangrove 
area which is quite difficult for the PO to monitor. Another concern is the insufficient manpower to monitor the entire mangrove area everyday. The number of manpower that monitors the area is five persons. The PO cannot afford to compensate those members that monitor the area everyday. In this case, the members are allotting five hours only to monitor in which they need to consume most of their time to work for their livelihoods like fishing and farming. In order to address financial issues on rehabilitation, they open the mangrove area for tourism activities since 2011. Unfortunately, some equipment for their tourism activities that they invested like lights, wires, cable etc. are being stolen.

\subsection{Best Practices and Strategies in Mangrove Rehabilitation}

At present, the 7.5 hectares mangrove area composed of grew and healthy mangroves species such as Avicennia marina (Bungalon), Avicennia alba (Bungalonputi), Rhizophora stylosa (BakhauanBato), and Sonneratia alba (Pagatpat) and mangrove associated species which include: Pongamiapinnata, Thespesia populnae, Sesuviumportulacastrum, Ipomeapescapre, Terminalia catappa, Acacia farnesiana and Morindacitrifolia. Based from the PO, scientific planting strategies are very crucial to consider in planting and growing of mangroves. Ms. Primavera, Municipal Agriculturist Office and Department of Environment and Natural resources (DENR) provided technical support for their rehabilitation. They prefer to plant propagules than seedlings for the reason that propagules are more resilient to wind and water current, unlike seedlings. In planting propagules, they were using a bamboo stick (patpat) and small size rope for temporarily support against wind and water current. They continuously monitor the new planted propagules to assure that each propagule will live and survive. In case that there are dead propagules then they will immediately replace it. The estimated survival rate of mangrove based on PO is $80 \%$. In addition, they highly consider the zonation in planting in which every species of mangroves are being planted in a specific area based on its characteristics. The PO decided to plant more species of mangroves for resiliency purposes against pest and diseases. The manpower for planting, maintenance and monitoring are solely shouldered by the PO. Another strategy for their rehabilitation as mentioned by the PO Treasurer, Ms. Ruth Helen E. Ricasa, "voluntarism at commitment ng bawatmiyembro ng PALITAKAN ang pinakanaging strategy naminupangmagingmatagumpay ang pagrerehabilitate ng amingbakawan".

Ecotourism development is also their best practice to promote the place and to generate funds for the maintenance and monitoring of their mangrove area as well as another source of income of the members of PO. Their ecotourism activities are mangrove tour and study tour (Php 150.00 for locals and Php 250.00 for foreigners), research activity (Php 200.00), kayaking (Php 200.00/hour), swimming (covered by the entrance fee amounting Php 100.00 for locals and Php 200.00 for foreigners), use of balsa, a floating flat structure made from bamboo (Php 2,500.00/day), mangrove planting (Php 150.00/propagule plus a certificate of planting from PO) and bird watching. They invested some facilities such as boat (Php 3,000.00/day), cottage (Php 700.00/day and Php 900.00 for overnight), life vest and snorkeling gears (Php 250.00). The tour guides and boatmen are members of PO which serves as their mechanism for additional income. Out of 30 active members, 12 are tour guides and 12 are boatmen. The income of tour guides and boatmen are both $20 \%$ of the fee and the rest will go to the fund of PO that will be used for other investments in tourism activities like boardwalk (replacement every three years), maintenance and monitoring of mangrove area. The average monthly tourist arrival during high season is 400 (March, April and May) while 20 during low season (June to October and December to February) and 0 when no season (November) and the Total Annual Income last 2016 is Php 141, 708.00.

Fishing and Gleaning are other livelihood activities in which both members and non-members of PO are allowed. Their usual catch is shrimp, crabs, octopus, and reef fishes. In addition, they are also practicing aqua silviculture through nurturing Halaan or Clam (Venerupisphilippinarum). The PO promotes resiliency in which based on them, their livelihood activities must not be always dependent on the mangrove area. They are doing farming as an alternative livelihood in order to lessen the stress on mangroves. Their usual crops are Sugar cane, Banana, Mango and vegetables. 
The provincial government of Batangas awarded the BRAVO Award to Calatagan Mangrove Forest Conservation Park as First Place during the $2^{\text {nd }}$ Batangas Recognition Award for Verde Passages Outstanding marine Protected Areas and Best BantayDagat on November 11, 2015, at Batangas City.

\subsection{Key Considerations in Mangrove Rehabilitation}

Policy

The PO's adopted existing laws and forest rules and regulations in the management of mangroves and resources therein in providing any policy within the organization. Hence, pursuant to Executive Order No. 192 and the Coastal Environment Program the DENR Administrative Order No. 30, series of 1994 was the promulgation of the implementing guidelines for the Non-Government Organization Assisted Community-Based Mangrove Forest Management (NGO-Assisted CBMFM) for the DENR. It has the primary objective to transfer all existing traditionally-depended upon mangrove forests under effective community-based management. In fact, they have adopted and rehabilitated the site in line with that Administrative Order to promote environmental awareness, social equity, economic development and sustainable resources management on such coastal communities. In accordance also with the provisions of Presidential Decree 705, otherwise known as the "Revised Forestry Code of the Philippines", as amended, the DENR Administrative Order No. 76, series of 1987 provided regulations governing the establishment of buffer zones in coastal and estuarine mangrove areas. Thus, the buffer zone of the park contributed to enhance the protective capability of the mangroves against strong currents, winds and high waves and to prevent siltation and sedimentation of the area. Moreover, the DENR Administrative Order no. 15, series of 1990 is a regulation governing the utilization, development and management of mangrove resources. Within such context, the PO's also make sure that the park is close from poaching and illegal activities and exploitation. They have close monitoring and surveillance of the area to prevent any illegal acts. Although, in accordance with that DENR administrative order the local community or PO's may have the exclusive right to cut, collect or remove mangrove forest products, such as firewood and mangrove timber for charcoal production for home consumption. It is however strictly mandated to be in accordance with existing laws and forest rules and regulations. Republic Act 9003 otherwise known as Ecological Solid Wastes Management Act is their main basis for wastes management in the mangrove area. All guests and tourists in the area are highly prohibitedfrom disposing wastes or else fines will be collected. In addition, they are also adopting the Republic Act 8550 otherwise known as the Fisheries Code of the Philippines in the protection and management of mangroves and resources therein.

\section{Scientific and Ecological Preferences}

In the planting of mangroves, the PO considers the scientific way in which there is a distance of one meter apart from each propagule. They prefer to use propagules in planting than seedlings for the reason that propagules are more resilient to wind and water current unlike seedlings. In planting propagules, they were using a bamboo stick and small size rope for temporarily support against wind and water current. Furthermore, they highly consider the zonation in planting in which every species of mangroves is being planted in a specific area based on its characteristics for the assurance of survival.

In addition, the PO preferred to plant a variety of mangrove species in order to be more resilient against pest and diseases. In case of disease on a certain species at a specific period of time, there are still many other species that are free from diseases in which the diversity of mangrove area contributes to its ecological resiliency.

\section{Participatory Approaches}

The current total PO members is 40 in which only 30 are active. Each member has a specific role with regard to mangrove management and other activities like ecotourism. In the planting of mangroves, all members are required to participate and they encourage the non-members to participate. There are 24 members that are mainly responsible for ecotourism activities in which 12 are tour guides and 12 are boatmen. There are five 
members that are mainly responsible for monitoring the entire mangrove area including the invested facilities by the PO. The rest of the members are mainly responsible for administration, planting, and replacing dead propagules.

\section{CONCLUSION}

After seven years of mangrove rehabilitation for 7.5 hectares, the area was dominated by some grown mangrove species which include, Avicennia marina (Bungalon), Avicennia alba (Bungalonputi), Rhizophora stylosa (BakhawBato), and Sonneratia alba (Pagatpat) and mangrove associated species which include: Pongamiapinnata, Thespesia populnae, Sesuviumportulacastrum, Ipomeapescapre, Terminalia catappa, Acacia farnesiana and Morindacitrifolia. The PO members are continuously planting the vacant area using propagules. The mangrove area serves as a source of food to the local people such as prawns, shrimps, crabs, shells and fishes. Their catches from mangrove area are both for household consumption and commercial use as their source of income.

In addition, the rehabilitated mangrove area was already engaged in ecotourism activities. The ecotourism activities are mangrove tour and study tour, research activity, kayaking, swimming, use of balsa, a floating flat structure made from bamboo, mangrove planting and bird watching. The tourism activities serve as another source of income to PO members as tour guides and boatmen. The income of tour guides and boatmen are both $20 \%$ of the fee and the rest will go to the fund of PO that will be used for other investments in tourism activities like boardwalk (replacement every three years), maintenance and monitoring of mangrove area. The average monthly tourist arrival during high season is 400 (March, April and May) while 20 during low season (June to October and December to February) and 0 when no season (November) and the Total Annual Income last 2016 is Php 141, 708.00.

The PO members are cooperating with each other for continuous planting and management of the rehabilitated area with the support of some institutions.

\section{RECOMMENDATIONS}

Based on the results, the researchers highly recommended the following:

Zonation pattern must be considered in planting mangrove species. It is classified into sea ward zone, middle zone, and land ward. Based from Melana et al. (2000), the species of mangroves that can be planted in seaward zone are Avicennia marina (Bungalon), Sonneratia alba (Pagatpat), Rhizophora stylosa or BakhawBato(if the substrate is coral rubble or sand) and Rhizophora appiculata or Bakhawlalaki(if the substrate sandy loam and silty). In the middle zone, the species of mangroves that can be planted are Rhizophora mucronata (Bakhawbabae), Rhizophora appiculata (Bakhawlalaki), Avicenniaoficinalis (Api-api), Avicennia alba (Bungalonputi), Bruguieracylindrica (Pototanlalaki), and Bruguieragymnorrhiza (Busain). The species of mangroves that can be planted in land ward are Ceriopstagal or Tangal(if the substrate is silty to silty clay), Nypafruticans or Nipa (if the substrate is silty to silty clay and only when there is freshwater intrusion) and Bruguierasexangula (Pototan). These approaches will be very essential in order to attain ecological resiliency of mangrove area (Melana et al., 2000)

Best collection times of propagules of every species is very essential to consider to attain ecological resiliency of mangrove area (Melana et al., 2000). Quilitisan, Calatagan, Batangas is a Type I Climate (Bareja, 2011) which has two pronounced season, dry from November to April and wet during the rest of the year (PAGASA, 2018). Based from Melana et al. (2000), in Type I climate, the best collection time for the following species: Bakhawlalaki (August and September), Bakhawbabae (October to December), BakhawBato (January and May), Tangal (May), Busain (January, October to December), Pototanlalaki (January to May and October), Api-api (January to February and May and July), Bungalon (April, July, November and December), Pagatpat (August to November) and Tabigi (August to November). 
As part of securing social resilience, the community may enhance and develop their other forms of livelihood like farming (Sugar cane and Mango as dominant crops in the area) in order to lessen the dependence to mangrove area in terms of livelihood.

Monitoring is very crucial in rehabilitating mangrove area. In this case, there must have regular monitoring of the entire mangrove area.

Lastly, develop other ecotourism activities like massage spa, souvenir shops and many others and to develop other approaches in promoting the place like websites and other means of social media.

\section{REFERENCES}

[1] Bareja, Ben G. (2011). Climate Types in the Philippines, Annual Rainfall and typhoon Frequency by region. Retrieved at http://www.cropsreview.com/climate-types.html on 5 May 2018.

[2] Carter, Haille N., Schmidt, Steffen W. and Hirons, Amy C. (2015). An International Assessment of Mangrove Management: Incorporation in Integrated Coastal Zone Management. Diversity Journal. ISSN 1424-2818, pp74-104.

[3] Daupan, Socorro Martha Meg-ay V. (2016). Community Participation in Mangrove Forest Management in the Philippines: Management Strategies, Influences to Participation, and Socio-Economic and environmental Impacts. Natural Resources and Environment, University of Michigan.

[4] Department of Environment and Natural Resources (2015). Philippine Forestry Statistics. Retrived at https://drive.google.com/file/d/0B1G5mTNoDPOFVEdpM3BqU2ZIS00/view on 27 April 2017

[5] FAO (2007). The Worlds Mangroves 1980-2005: A thematic study prepared in the framework of the global forest resources assessment 2005. FAO forestry paper 153, Food and Agriculture Organization of the United Nations, Rome, Italy.

[6] Grasso, M.(2000). Understanding. Modeling and Valuing the linkages between local communities and the mangroves of Caete's river bay, PA, Brazil. PhD thesis, Faculty of the graduate school of the University of Maryland, College Park, Maryland.

[7] Hema, M. and Indira Devi, P. (2015). Factors of Mangrove Destruction and Management of Mangrove Ecosystem of Kerala, India. Journal of Aquatic Biology and Fisheries Vol. 2, pp. 184-196.

[8] Melana, D.M., J. Atchue III, C.E. Yao, R. Edwards, E.E. Melana and H.I. Gonzales (2000). Mangrove Management Handbook. Department of Environment and Natural Resources, Manila, Philippines through the Coastal Resource Management Project, Cebu City, Philippines. 96 p.

[9] Naz, Antonia Corinthia (2013). The State of the Philippine Environment: An Update on Chapter 4 of the 1994 Philippine Human Development Report. PHDR Issue 2012/2013, No. 10. Human Development Network.

[10] PAGASA (2018). Climate Projections. Retrieved at https://www1.pagasa.dost.gov.ph/index.php/93-cad1/472-climate-projections

[11] United Nations University-Institute for Water, Environment and Health (2016). The Benefits of Mangroves. 